\title{
Archipel
}

ARCHIPEL Études interdisciplinaires sur le monde insulindien

$101 \mid 2021$

Varia

Campbell Macknight, Mukhlis Paeni and Muhlis

Hadrawi (ed. \& trans.), The Bugis Chronicle of Bone.

Canberra, ANU Press, 2020.153 p.

ISBN9781760463571 (print); 9781760463588 (online

from press.anu.edu.au)

\section{Anthony Reid}

\section{CpenEdition}

Édition électronique

URL : https://journals.openedition.org/archipel/2429

DOI : 10.4000/archipel.2429

ISSN : 2104-3655

Éditeur

Association Archipel

Édition imprimée

Date de publication : 30 juin 2021

Pagination : 251-252

ISBN : 978-2-910513-85-6

ISSN : 0044-8613

Référence électronique

Anthony Reid, «Campbell Macknight, Mukhlis Paeni and Muhlis Hadrawi (ed. \& trans.), The Bugis

Chronicle of Bone. Canberra, ANU Press, 2020. 153 p. ISBN9781760463571 (print); 9781760463588

(online from press.anu.edu.au) », Archipel [En ligne], 101 | 2021, mis en ligne le 12 juin 2021, consulté le 02 juillet 2021. URL : http://journals.openedition.org/archipel/2429; DOI : https://doi.org/10.4000/ archipel.2429 
Campbell Macknight, Mukhlis Paeni and Muhlis Hadrawi (ed. \& trans.), The Bugis Chronicle of Bone. Canberra, ANU Press, 2020. 153 p. ISBN9781760463571 (print); 9781760463588 (online from press.anu.edu.au).

The modest community of scholars and students of Bugis-Makassar culture and history have much reason to be grateful to Campbell Macknight and his two Bugis colleagues. They have persevered over a half-century of other demands on the time of each of them, as well as changing expectations and conventions of Bugis scholarship, to bring this very difficult project to fruition during the fruitful retirement of the two initial collaborators, Macknight and Mukhlis.

Campbell Macknight deserves special gratitude for having taken up the supreme challenge for an outsider of pursuing the sources to their scholarly base. Having first discovered South Sulawesi culture as an Australian archaeologist interested primarily in Sulawesi's contribution to Australia's deep history, he recognised that the Bugis and Makassar also have their very distinctive internal voices in the form of remarkably realistic chronicles of each royal tradition. Since the Bugis and Makassar texts in the former Matthes-Stichting (continued after independence as the Yayasan Kebudayaan Sulawesi Selatan dan Tenggara) in Makassar seemed far from secure, he personally microfilmed them for deposit in the ANU Library to ensure that there would be duplicates in the case of loss. Leonard Andaya is acknowledged as having arranged the photocopying of six further Bone texts in 1976 to add to the ANU Library collection.

The Dutch tradition of Indology, which made the scholarly editing and translating of an important Indonesian manuscript a common topic for a $\mathrm{PhD}$, and indeed for the training of colonial officials, is no more. Very few Bugis or Makassar texts have been expertly edited since Noorduyn closed the Dutch era at a very high level with his Wajo chronicle (1955). It would today be considered a dangerously unprofitable choice of topic for a PhD, even in Indonesia. Although the Ministry of Education sponsored the translation into Indonesian of numerous chronicles in the 1980s, it cannot yet be said that the discipline of text editing is yet very securely placed in Indonesia. Every such text that emerges is therefore of immense value, particularly for historians like me.

The erudition behind this edition has been accumulating over decades, and shows at every step of the way. Macknight and the other authors have published widely meanwhile on the methodology of rendering a text written on lontar leaves in Bugis script without word or sentence breaks into roman characters and modern understanding of sentence structure. Happily they have adopted modern Indonesian place-names for the English text, notably omitting the glottal stop (Wajo') of the Bugis text . They have opted to present a "diplomatic edition, which seeks to provide an exact account of... one manuscript," rather than a "critical edition" using all texts to construct the presumed intention of the original author (pp. 7-8). The other known manuscripts are similar in essential content, explaining the genealogy of rulership from the original heaven-descended tomanurung to the crisis of the $1660 \mathrm{~s}$ when the Dutch conquered Makassar and their ally Aru Palakka took charge of Bone. Their choice fell on NBG 101 of the Bible Society, now in Leiden, collected during the Dutch seizure of the Queen of Bone's house in 1859. It was at least among the oldest and best-credentialed as belonging to the court, and moreover was unusually clearly and consistently written. 
Bone has not hitherto gained the attention it merits as the largest and strongest Bugis state at most times since states can be documented in the fifteenth century. Makassar (Gowa-Tallo) demanded attention for what I call the "Makassar enlightenment" of the $17^{\text {th }}$ century, as well as its international importance; Wajo for the unique value its chronicles placed on personal freedom, and its diaspora admired as sailors, soldiers and even authors throughout Nusantara; Luwu as the acknowledged "eldest" of the Bugis states and presumed home of the La Galigo epic about a mythical remote past. By contrast Bone may have been underrated as the Sparta of South Sulawesi, more important for its power than its cultural achievements.

Neither the chronicler nor the editors of this chronicle make it their business to correct (or confirm) this stereotype. The editors are concerned to present the text as honestly and correctly as possible. Yet the historian hungry for controversy may note that although the chronicle is largely concerned with battles, conquests by Bone, and of course succession, the consent of the governed is still explicitly documented in a kind of social contract. Even more interesting is the prominence of queens in that line of succession, even into the nineteenth century when other Nusantara monarchies had largely abandoned the practice.

Finally, the great merit of this edition is to have published through ANU Press, which proclaims itself "Australia's first open-access university press." This whole book is available free to all on the website, creating a remarkable equality between Bugis teenager and Leiden Professor. I thank Archipel for making me proud possessor of the handsome print copy, also available from the press for a price. But one can be sure it will have a much more dynamic life in its electronic form.

Anthony Reid Australian National University

Farish A. Noor and Peter Carey (ed.), Racial Difference and the Colonial Wars of 19th Century Southeast Asia, Amsterdam, Amsterdam University Press, 2021. ISBN: 978 9463723725 ; ISBN Version pdf: 9789048550371

La violence de la colonisation, notamment les guerres qu'elle a engendrées, est au centre de l'ouvrage collectif dirigé par Farish Noor et Peter Carey. Le thème y est cependant revisité - et les guerres relues - au travers du prisme des discours raciaux produits, au 19e siècle, sur les populations de l'Asie du Sud-est. Cet ouvrage s'inscrit dans la lignée de trois autres monographies publiées par Farish Noor, à titre d'auteur, chez le même éditeur : The Discursive Construction of Southeast Asia in the 19th Century Colonial-Capitalist Discourse (2016), America's Encounters with Southeast Asia, 1800-1900 : Before the Pivot (2018) et Data-Gathering in Colonial Southeast Asia 1800-1900: Framing the Others (2019). Chacune de ces études aborde, à sa manière, la construction discursive de la région à partir de textes de la littérature coloniale considérés comme classiques. Tous trois sont à cet égard, selon les mots de l'auteur, " un livre sur des livres $»^{11}$. L'œuvre présentée ici analyse le rôle joué par ces livres, et d'autres écrits, lors des guerres et conflits coloniaux ayant agité Java, le Siam, Pahang, le nord de

11. "A book about books". 